\title{
Effect of Variations in Sugar Addition to the Quality of Bamboo Shoot Syrup \\ (Dendrocalamus asper)
}

\author{
Soleman Sayuna, James Ngginak, Merpiseldin Nitsae \\ Department of Biological Education, Faculty of Teacher Training and Education, Artha Wacana Christian \\ University, Oesapa, Kupang (NTT), Post Code: 85228. \\ email: Solemansayuna@gmail.com
}

\begin{abstract}
Betung bamboo (Dendrocalamus asper) is a clumping plant that has a phase of growing through shoots (bamboo shoots). Bamboo shoots contain phosphorus, vitamin A, vitamin $C$, mineral fiber, and protein. The purpose of this study was to determine the effect of variations in the addition of sugar to the quality of bamboo shoot syrup. The method used in this study was an experimental method with a completely randomized design $(C R D)$ to test organoleptic properties. Variations in the addition of sugar used in this study were $50 \%, 55 \%, 60 \%$, and $65 \%$. The results of the vitamin $C$ test were $2.112 \%, 3.256 \%, 4.136 \%$, and $5.016 \%$, respectively. Protein test results for each treatment were $0.25 \%, 0.15 \%, 0.24 \%$ and $0.17 \%$. The results of the water content test showed $0.073 \%, 0.063 \%$, $0.056 \%$ and $0.056 \%$. As well as the results of organoleptic tests (thickness, taste, and liking) showed the best treatment found at $65 \%$ sugar concentration with a value of 3.8000, 3.4667, and 3.6000. The results indicate there is an effect of sugar variation on vitamin $C$, water content, and organoleptic, but does not have an effect on protein content. Further research is needed to determine the nutritional value of fat, carbohydrates, Vitamin A, vitamin B1 (Thiamine), Vitamin B2 (Riboflavin), Fe, $K, C a, P$, $\mathrm{Na}$, and microorganism tests.
\end{abstract}

Keywords: syrup; vitamin C; sugar; bamboo shoots.

\section{INTRODUCTION}

Betung bamboo (Dendrocalamus asper) is a clumping plant belonging to the Gramineae tribe. This plant species is spread in the tropics, subtropics to temperate regions. Bamboo Betung has essential benefits for the community because it can be used for building construction, as household furniture and as food.

The young shoots can be processed into a variety of foods, such as crackers, flour, and nuggets (Rizkiyani et al., 2016; Harrower, 2014; Silaban et al., 2017). It has a good taste and also contains potassium to reduce blood pressure, phosphorus, vitamin $\mathrm{A}$, vitamin $\mathrm{C}$, mineral fibers, and protein (Rizkiyani et al., 2016). Other products created from bamboo shoots is syrup. This concentrated sugar solution is usually made from fruits, easily dissolved in water, contains vitamin C and anthocyanins (Wulansari, 2013).

The proportion of sugars in the syrup is affecting the color, taste, durability, and consistency of syrup (Fitri et al., 2017; Andita, 2016). The most common sugars used in syrup are white sugar and palm sugar.
Ordinary people have known sugar as a simple carbohydrate commonly consist of monosaccharides (glucose, fructose, and galactose) and disaccharides (sucrose, maltose, lactose, and trehalose) ((Salamba, 2018). According to Hartanto (2014), sugar is useful as a flavor enhancer and preservative in syrup. It also determines the quality of the product. Based on the description, this study aimed to find out the effect of sugar additions to the quality of bamboo shoot syrup that including the taste, viscosity, vitamin $\mathrm{C}$, and protein content.

\section{RESEARCH METHODS}

\section{Place and time of research}

This research was conducted at the Biology Laboratory of Artha Wacana Christian University from July to August 2019. Vitamin C level was measured in the Chemistry Lab FKIP Nusa Cendana University, whereas protein content was measured in BPOM Lab in Kupang.

\section{Tools and Materials}

Tools used in this study are counterweight, blender, plastic bowl, bucket, stove, pan, measuring cups $500 \mathrm{~mL}$ (Pyrex), stopwatch, 
plate, beaker glass, spoon, funnel (Pyrex), bottle (Glass), and thermometer.

Materials used in this study are bamboo shoot juice $250 \mathrm{~mL}$, citric acid $0,2 \%$, food coloring FDA approved, white sugar, aquadest, standard iodine, sulfuric acid $2 \%$, bromocresol green $0.1 \%$, alcohol 95\%, methyl red $0.1 \%$, hydrochloric acid $30 \%$, and sodium hydroxide.

\section{Research methods}

It is an experimental study using a completely randomized design (CRD) with five treatments of sugar concentration, namely $0 \%$, $5 \%, 55 \%, 60 \%$, and $65 \%$.

\section{Work procedures}

The making bamboo shoot syrup is explained as follows:

\section{Cooking preparation for syrup}

Fresh and clean bamboo shoots are cut into small pieces, weighed, washed in running water for 30 minutes, rewashed with salt solutions, and then steamed for about one hour. After steaming, it is washed and drained for a couple of times (Gervacia, 2017). These soft shoots are blended until it reached pulp-like consistency, and filtered with a fine sieve to obtain shoot juice. Citric acids $(0,2 \%)$, water, and food coloring then added. The mixture is added with sugars according to the concentration treatments while heated. The next step is bottling, pasteurization, and cooling down at room temperature (Wulansari, 2013).

\section{Vitamin C Test (Iodimetry Method)}

Iodimetric titration is used to test the vitamin $\mathrm{C}$ content in the syrup. Iodometric titration is a titration based on the reaction between iodine as the reactant. The basis of this method is the nature of reducing vitamin $\mathrm{C}$ and titration with iodine standard solution.

An Amylum solution $(0,1 \% ; 0,5 \mathrm{~mL})$ is added to $10 \mathrm{~mL}$ of syrup. Potassium iodide solution $0,01 \mathrm{~N}$ is dropped onto the syrup solution until form a slight blue color (Content and Wine, 2015). The percent of vitamin $\mathrm{C}$ is calculated using the following formula:

$$
\% \text { Vitamin } C=\frac{\text { Vol Iod } x \text { BE }}{\mathrm{v}} 100 \% .
$$

Voi iod $=$ iodime volume .

$\mathrm{BE}=$ Weight equivalent to vitamin $\mathrm{C}(0,88)$.

$\mathrm{V}$ = sample volume.

\section{Protein Test (Kjeldahl Method)}

The Kjeldahl method is used to measure the protein content. The working procedure in the Kjeldahl is divided into two stages: preparation for the reagent solution and the testing stage. The formula to determine the protein content is as follows:

\section{$\underline{\text { (v1-v2) x N x 0,014 x fk x fp }}$}

\section{W}

$\mathrm{v}_{1}: 0.01 \mathrm{~N} \mathrm{HCl}$ volume used in the sample

$\mathrm{v}_{2}: 0.01 \mathrm{~N} \mathrm{HCl}$ volume used as a blanko.

$\mathrm{N}$ : Normality of $\mathrm{HCl}$.

Fk: Conversion factor for protein.

Fp: Dilution factor.

W: Sample weight.

\section{Moisture Test}

The moisture test is carried out following Permatasari (2012). The Moisture formula is as follows:

$$
\% \text { Water content }=\frac{\mathrm{B}-\mathrm{C}}{\mathrm{B}-\mathrm{A}} \times 100
$$

A: Empty weight cup (g).

B: Weight of the cup filled with sample (g ).

$\mathrm{C}$ : Weight of the cup with the sample dried ( $\mathrm{g}$ ).

\section{Organoleptic test.}

The test is carried out with the hedonic scale scoring method using 30 semi-trained respondents consisting of 15 fruit ice traders and 15 students. The criteria assessed include thickness, taste, and likeness (Magelang et al., 2017). Table 1 presents the criteria for each organoleptic indicators.

Tabel 1. Test Scores for Taste, Viscosity, and Preference.

\begin{tabular}{clll}
\hline Score & Viscosity & Taste & Preference \\
\hline 4 & Very thick & $\begin{array}{l}\text { Very } \\
\text { sugary }\end{array}$ & Really like \\
\hline 3 & Thick & Sugary & Like it \\
\hline 2 & Not thick & Neutral & Neutral \\
\hline 1 & $\begin{array}{l}\text { Not thick } \\
\text { enough }\end{array}$ & $\begin{array}{l}\text { Not } \\
\text { Sugary }\end{array}$ & Do not like \\
\hline
\end{tabular}

(Magee et al., 2017) 
Data analysis technique.

All the qualitative data are analyzed using one-way ANOVA, followed by DMRT (Putri, 2016).

\section{RESULTS AND DISCUSSION}

Level of Vitamin C

The level of vitamin $\mathrm{C}$ is presented in Table 2.

Table 2. Contents of Vitamin $\mathrm{C}$ in Bamboo Shoot Syrup.

\begin{tabular}{ccc}
\hline No & Sample Code & $\begin{array}{c}\text { Vitamin C levels } \\
(\%)\end{array}$ \\
\hline 1 & P1 & 2,112 \\
2 & P2 & 3,256 \\
3 & P3 & 4,136 \\
4 & P4 & 5,016 \\
\hline
\end{tabular}

Based on Tabel 2, the value of vitamin $\mathrm{C}$ different in each treatment. The higher the sugar concentration, the higher the value of vitamin C. ( $\mathrm{P}$ is code for sugar concentrations). The concentration of sugar $65 \%$ has the highest levels of vitamin C, which is 5,016\%. Sugar has hygroscopic properties. It absorbs water from the cell walls of shoots during cooking. Vitamin C might come out along with water to the surrounding. Sugar is not a source of vitamin C, but the administration of sugar accompanied by a heating process can accelerate sugar to bind water and vitamin $\mathrm{C}$ from within the cell walls of plants (Rahmasari and Susanto, 2014; Ngginak et al., 2019). However, vitamin $\mathrm{C}$ is also easily oxidized if exposed to high temperatures or excessive mechanical actions.

\section{Protein Content}

Table 3 presents the result of the Kjeldahl method.

Tabel 3. The Protein Content of the syrup

\begin{tabular}{clc}
\hline No & $\begin{array}{c}\text { Sample } \\
\text { Code }\end{array}$ & $\begin{array}{c}\text { Protein Analysis } \\
\text { Results }(\%)\end{array}$ \\
\hline 1 & P1 & 0,25 \\
2 & P2 & 0,15 \\
3 & P3 & 0,24 \\
4 & P4 & 0,17 \\
\hline
\end{tabular}

The highest value is in the treatment of $50 \%$ sugar, while the lowest value of protein content is in the treatment of $55 \%$ sugar. Sugar does not provide a positive correlation on protein content. The sole source of protein provided by the shoot. There is $2.5 \%$ protein for each $100 \mathrm{~g}$ of raw bamboo shoot (Wahanani, 2014). The result showed much lower protein content due to denaturation during heating process. Filtering might play a role in decreasing protein as well because most proteins were left intact in the tissue. Protein is easily denatured or damaged when given mechanical treatment and excessive heat exposure. The protein will break the peptide bonds that support the secondary, tertiary, and quaternary structures of the polypeptide chains (Manis et al., 2017).

\section{Moisture Content}

The water analysis was measured using the gravimetric test.

Table 4. Water Content

\begin{tabular}{ccc}
\hline No & $\begin{array}{c}\text { Sample } \\
\text { Code }\end{array}$ & $\begin{array}{c}\text { Water Analysis } \\
\text { Results (\%) }\end{array}$ \\
\hline 1 & P1 & 0.073 \\
\hline 2 & P2 & 0,063 \\
\hline 3 & P3 & 0,056 \\
\hline 4 & P4 & 0,056 \\
\hline
\end{tabular}

Table 4 implies that the water content is reduced or inversely proportional to the sugar concentration. The higher the sugar concentration, the less water content. It is due to the ability of sugar to absorb and reduce water. Sugar has hygroscopic properties due to the presence of free and reactive polyhydroxyl groups. Polyhydroxyl groups are capable of binding to hydrogen because of ambient temperature and pH (Andika, 2015). Polyhydroxyl and aldehyde groups in sugars have a significant role in chemical reactions such as hydrolysis, oxidation, and reduction. Osmotic pressure during the heating process might also affect the water content of the syrup.

\section{Organoleptic Test}

Table 5. ANOVA Test on the organoleptic Parameters of Viscosity.

\begin{tabular}{cccccc}
\hline Viscosity & $\begin{array}{c}\text { Sum of } \\
\text { Squares }\end{array}$ & Df & Square & F & Sig. \\
\hline $\begin{array}{c}\text { Between } \\
\text { Groups }\end{array}$ & 31.892 & 3 & 10.631 & 16.56 & 0.000 \\
\hline $\begin{array}{c}\text { Within } \\
\text { Groups }\end{array}$ & 74.433 & 116 & .642 & & \\
\hline
\end{tabular}


Table 5. ANOVA Test on the organoleptic Parameters of Viscosity.

\begin{tabular}{cccccc}
\hline Viscosity & $\begin{array}{c}\text { Sum of } \\
\text { Squares }\end{array}$ & Df & Square & F & Sig. \\
\hline $\begin{array}{c}\text { Between } \\
\text { Groups }\end{array}$ & 31.892 & 3 & 10.631 & 16.56 & 0.000 \\
\hline $\begin{array}{c}\text { Within } \\
\text { Groups }\end{array}$ & 74.433 & 116 & .642 & \\
\hline Total & 106.325 & 119 & & \\
\hline
\end{tabular}

The p-value is $<0.05$ shows that there is a difference in viscosity between treatments. The DMRT is presented in Table 6.

Table 6. DMRT result of viscosity.

\begin{tabular}{cccc}
\hline & & \multicolumn{2}{c}{ Subset for alpha $=0.05$} \\
\cline { 3 - 4 } Viscosity & $\mathrm{N}$ & 1 & 2 \\
\hline P2 & 30 & 2.4667 & \\
\hline P3 & 30 & 2.7000 \\
\hline P1 & 30 & 2.7333 & \\
\hline P4 & 30 & & 3.8000 \\
\hline Sig. & & .228 & 1.000
\end{tabular}

Note: " Very significant difference in DMRT test, P1: 50\% sugar, P2: 55\% sugar, P3: 60\% sugar, P4: $65 \%$ sugar.

The 65\% sugar concentration has the highest viscosity, according to respondents. It gets a value of 3.8000 higher compared to $50 \%$ (2.7333), 60\% (2.7000), and 55\% sugar (2.4667). The high viscosity is due to the presence of dissolved sugar particles. The higher the total amount of dissolved solids, the higher the viscosity value (Pratama et al., 2014).

Table 7 presents the Anova result of flavor quality.

Table 7. Anova Test on the flavor.

\begin{tabular}{|c|c|c|c|c|c|}
\hline Taste & $\begin{array}{l}\text { Sum of } \\
\text { Squares }\end{array}$ & Df & $\begin{array}{l}\text { Mean } \\
\text { Square }\end{array}$ & $\mathrm{F}$ & Sig. \\
\hline $\begin{array}{c}\text { Between } \\
\text { Groups }\end{array}$ & 10.692 & 3 & 3.564 & 5.035 & 0.003 \\
\hline $\begin{array}{l}\text { Within } \\
\text { Groups }\end{array}$ & 82.100 & 116 & .708 & & \\
\hline Total & 92.792 & 119 & & & \\
\hline
\end{tabular}

Bioedukasi Vol. XVIII No. 1 April 2020
Table 8. DMRT result of flavor.

\begin{tabular}{cccc}
\hline & & \multicolumn{2}{c}{ Subset for alpha $=0.05$} \\
\cline { 3 - 4 } Taste & $\mathrm{N}$ & 1 & 2 \\
\hline P2 & 30 & 2.7000 & \\
\hline P1 & 30 & 2.8333 \\
\hline P3 & 30 & 2.8333 & \\
\hline P4 & 30 & & 3.4667 \\
\hline Sig. & & .567 & 1.000
\end{tabular}

Note: " Very significant difference in DMRT test, P1: 50\% sugar, P2: $55 \%$ sugar, $60 \%$ sugar P3, P4: $65 \%$ sugar.

The $65 \%$ sugar concentration has the best flavor, according to respondents. It gets a value of 3.4667 higher. Apart from giving a sweet taste, sugar also inhibits the growth of fungi and bacteria in food ingredients (Susanti, 2016).

Table 9 present the Anova result of preference.

Table 9. Anova results in the syrup preference.

\begin{tabular}{cccccc}
\hline Preference & $\begin{array}{c}\text { Sum of } \\
\text { Squares }\end{array}$ & Df & $\begin{array}{c}\text { Sean } \\
\text { Square }\end{array}$ & F & Sig. \\
\hline $\begin{array}{c}\text { Between } \\
\text { Groups }\end{array}$ & 10.692 & 3 & 3.564 & 5.035 & 0.003 \\
\hline $\begin{array}{c}\text { Within } \\
\text { Groups }\end{array}$ & 82.100 & 116 & .708 & & \\
\hline Total & 92.792 & 119 & & & \\
\hline
\end{tabular}

The $p$-value is $<0.05$ shows that there is a difference in preference between treatments. The DMRT is presented in Table 10.

Table 10. DMRT result of preference

\begin{tabular}{cccc} 
& & \multicolumn{2}{c}{ Subset for alpha $=0.05$} \\
\cline { 3 - 4 } Passions & $\mathrm{N}$ & 1 & 2 \\
\hline P3 & 30 & 2.8000 & \\
\hline P2 & 30 & 2.9667 & \\
\hline P1 & 30 & 3.0333 & \\
\hline P4 & 30 & & 3.6000 \\
\hline Sig. & & .270 & 1.000
\end{tabular}

Note: " Very significant difference in DMRT test, P1: 50\% sugar, $\mathrm{P} 2:$ 55\% sugar, $60 \%$ sugar $\mathrm{P} 3$, P4: 65\% sugar.

The $65 \%$ sugar concentration treatment has a different effect on preference parameters because it gets a higher value of 3.6000 compared to the 50\% sugar (3.0333), 55\% sugar (2.9667), and 60\% sugar (2.8000). The 65\% sugar concentration treatment is most preferred 
by panelists because it has a thicker texture and has a sweeter taste. This result is consistent with the commentary sheet on the questionnaire filled by panelists.

\section{CONCLUSION}

The sugar concentrations affect the vitamin $\mathrm{C}$ level and water content but don't influence protein content. The most recommended sugar concentration based on the organoleptic test is $65 \%$ sugars.

\section{REFERENCE}

Andita Putri, R. (2016). Effect of Proportion of Sugar on Organoleptic Properties of Starfruit Syrup. Journal of Catering, 5 (3), 73-82

Andhika, P. (2015). Identification of Changes in Physical Characteristics of Granulated Sugar Due to the Milling Process During Storage and Use of Packaging on a Laboratory Scale. Bogor Agricultural Institute.

Ariesta, T. A. (2012). The production process of making sweet starfruit syrup. 1-42.

Fitri, E., Harun, N., \& Johan, V. S. (2017). Sugar and Fruit Juice Concentration on the Quality of Starfruit Syrup (Averrhoa bilimbi L.). JOM Faperta UR, 4 (1), 1-13.

Gervacia, R. I. (2017). Journal of Equatorial Laboratory Analysis of Cyanide Levels in Bamboo Shoots Before and After Steaming for 10,15 , and 20 Minutes of Selective Ion Electrode Methods. 059 (1), 8-12.

Hartanto, E. S. (2014). CARBONATED REMELT DEFECATION Product Quality Improvement of White Crystal Sugar through Defecation Remelt Carbonatation Technology. Quality, Sugar Enhancement, White Products, Technology Crystals, Through,215-222.

Silaban, M., Herawati, N., \& Zalfiatri, Y. (2017). Effect of adding betung bamboo shoots in making catfish nuggets (Pangasius hypothalamus). Jom Faperta, 4 (2), 1-13.

Salamba, W. A., Science, F., \& Technology, D. A. N. (2018). Synthesis of Carbon Dots (C-Dots) from Granulated Sugar Material Using Microwave Technique to Detect Iron Heavy Metal (Fe 3+) Thesis Submitted to Meet One of the Requirements to Achieve a Bachelor Degree in Physics at the Faculty of Science and Technology of UIN Alauddin.
Harrower, B. M. (2014). Physical Quality and Characteristics of Bamboo Flour. No Title. 19(1),55.http://eprints.uanl.mx/5481/1/10201499 95.PDF.

Kadar, D. A. P., \& Grapes, V. C. (2015). Available online at $\mathrm{http}$ ://ejurnalanaliskKesehatan.web.id Effect of Calcium Chloride ( $\mathrm{Cacl} 2$ ) And Storage Duration Against Vitamins Vitamin (Vitis vinifera). 1 (12), 61-71.

Ministry of Trade. (2011). Exploring Export Opportunities for Products from Bamboo. Export News, 20.

Manis, I., Supriadi, \& Said, I. (2017). Chemical Education/Faculty of Politics-Universitas Tadulako, Palu-Indonesia 94118. 6 (November), 219-226.

Magee, RV, Crowder, R., Winters, DE, Beerbower, E., Bodhi, B., Schindler, S., Pfattheicher, S., Reinhard, M.-A., Haddock, G., Foad, C., Windsor-Shellard, B., Dummel, S., AdarvesYorno, I., Furlotte, C., \& Gorski, PC (2017). No Title. Effect of Sucrose Addition on Organoleptic Characteristics, Melting Time, and Coffee Cream Ice Cream Overrun. ABA Journal, 102 (4), 24-25. https://doi.org/10.1002/ejsp.2570

Magelang, U. M., Muhyiddin, M. F., \& Harismah, K. (2017). Organoleptic Analysis and pH on Quality of Stevia Syrup Clove (Syzygium aromaticum). 69-74.

Ngginak, J., Dian, A., Rupidara, N., Daud, Y., \& Ntt, K. (2019). The content of Vitamin C from Fig (Ficus carica L.) And Forest passion fruit (Passiflora foetida L.) extracts. 2 (2), 54-59.

Pakaya, D. (2014). The Role of Vitamin C on the Skin. Medical Scientific Journal, 1 (2), 45-54. Http://Jurnal.Untad.Ac.Id/Jurnal/Index.Php/Medi katadulako/Article/View/7932/6271.

Permatasari, M. (2012). Changes in Antioxidant Activity of Plant Genjer (Limnocharis flava) due to steaming. Thesis Department of Aquatic Product Technology, Faculty of Fisheries and Marine Sciences, ITB

Pratama, S. B., Wijana, S., \& Febriyanto, A. (2014). Tamarillo Syrup Making Study (Comparative Study of Fruit and Sugar Concentration) Study of Making Tamarillo Syrup (The Effect of Fruit Proportion and Concentration of Sugar). J Industria, 1 (3), 180-193.

Rahmasari, H., \& Susanto, W. H. (2014). Osmosis extraction in the manufacture of Mulberry syrup (Morus alba L.) studies the proportion of fruit: Sucrose and Osmosis time. Journal of Food and 
Agro-Industry, 2 (3), 191-197.

Rizkiyani, N., Kamal, R., \& Hamid, Yuli Heirina. (2016). Effect of Addition of Rebung Betung Scientific Journal of Family Welfare Education Students, 1 (1), 25-31.

Susanti, C. (2016). Effect of Comparison of Red Dragon Fruit Juice (Hylocereus polyrhizus) with Hunched Salacca Juice (Salacca edulis Reinw) And Type of Stabilizer Against Characteristics of Fruit Syrup. Articles on Fruit Syrup from Mixed Red Dragon Fruit Juice and Hunched Salak Fruit Juice, 1-18.

Wulandari, D.E. (2014). No Utilization of Bamboo Shoots (Bamboo Buds) into Nuggets with the addition of Turmeric as a Natural Preservative Title. Implementation Science, 39(1),1-15. Https://Doi.Org/10.4324/9781315853178.

Wulansari, N., Mahawati, E., \& Hartini, E. (2013). No Effect of Difference in Sugar Addition on Characteristics of Red Dragon Fruit Syrup (Hylocereus polyrhizus) Title. 